\title{
The Use of Internet Media in The Fulfilling Of Rights About Education in The Atmosphere Of The Covid-19 Pandemic: Human Rights Perspective
}

\author{
Agus Triyanto \\ \{surianiagus1976@gmail.com\} \\ MAN 2 Kota Makassar, Jl.Ap. Petarani No. 1
}

\begin{abstract}
The right of education is very important based on the government policy to work from home or learn from in Covid 19 Pandemic Situation. The aim of this writing is to explain the importance of education right in covid 19 Pandemic in relation to the rights of information from using internet. The method used is Normative Juridical using human right law provisions that place information as an important part of education right. The study shows the quarantines and protection of the education and information right need to do in a planned manner by the government and education providers even in covid 19 pandemic. The right construction of education is closely related to the right of information in covid 19 pandemic.
\end{abstract}

Keywords: the education rights; information right; covid-19; human rights

\section{Introduction}

Early March 2020 the President of the Republic of Indonesia instructed both work from home and study from home. Work from home / study from home for the world of business and education, has an impact on the pattern of education throughout the world, including Indonesia. The work from home policy was emphasized by the issuance of Presidential Decree No.11 of 2020 concerning the Determination of Covid-19 Public Health Emergencies. Furthermore, in Government Regulation 21/2020 concerning Large-Scale Social Restrictions in the Context of Accelerating the Handling of Covid-19 (PP 21/2000). These two regulations are a sign that the Government is choosing the PSBB strategy from other health quarantine options offered by Law Number 6 of 2018 concerning Health Quarantine. The legal products issued by the government have also become the basis of reference for implementing the PSBB in several regions.

PSBB is a response to a public health emergency. Large-scale social restrictions lie in the strategy of school and work vacations, restrictions on religious activities; restrictions on activities in public places or restrictions on gathering. PSBB has an impact on people's lives, especially in the field of education. The education strategy has also changed drastically from conscious and planned efforts (Article 31 Paragraph (2) of Law Number 20 of 2003 concerning the National Education System / National Education System Law) to being adaptive by utilizing information technology. In particular, the National Education System Law provides for provisions related to distance education. It's just that the design of distance education in question is not necessarily the same as information technology-based education in this large-scale social limitation period. Distance education is intended for groups of people who cannot attend faceto-face education. That is, the ideal design of education is emphasized face-to-face between 
educators and students. Implicitly distance education is the last choice for groups of people who are constrained from not being able to attend face-to-face education. This is a challenge in itself considering that distance education using technology is the only way to carry out education during the Covid-19 Pandemic.

Based on the latest We Are Social report, in 2020 it was stated that there were 175.4 million internet users in Indonesia. Compared to the previous year, there was an increase of $17 \%$ or 25 million internet users in Indonesia. Percentage of internet users aged 16 to 64 who own each type of device, including mobile phones (96\%), smartphones (94\%), non-smartphone mobile phones $(21 \%)$, laptops or desktop computers $(66 \%)$, table (23\%), game consoles (16\%), to virtual reality devices $(5.1 \%)$. In this report it is also known that currently 338.2 million Indonesians who use cell phones.

The use of information technology for education is not new. Data on the penetration of internet users in Indonesia from APJII's research in 2018, internet users in Indonesia reached 171.17 million from 264.16 million people (64.8\%). Based on the age of internet users, it appears prominent at the age of 5-9 years as much as $25.2 \%, 10-14$ years as much as $66.2 \%$, aged $15-19$ years as much as $91 \%$, aged $20-24$ years as much as $88.5 \%$, aged $25-29$ years as much as $82.7 \%$. If this data is related to the level of formal education, that the age of primary education (7-15 years) is familiar with and used to using the internet, the age of secondary education (16-18 years) is also prominent in internet use, as well as the age of higher education ( $\geq 19$ year). The data shows that the use of the internet for education is not new and foreign.

The Covid-19 pandemic has forcibly changed face-to-face formal education into formal education with the form of online learning. The need for education has shifted from economic needs, transportation and financing to support education to become expensive because electronic devices that can be connected via the internet and internet connectivity are required. This condition is not an easy thing for education providers, educators and students. The determination of the PSBB in several areas has an impact on the provision of facilities and internet connectivity, which are still not all reachable. This condition requires an in-depth study of the human rights building regarding education during the Covid-19 Pandemic on the other hand.

\section{Research Methods}

Based on the conditions of the Covid-19 Pandemic which was supported by the PSBB strategy by the government related to the challenges of implementing education in order to keep it running, there were several issues that were discussed further: (1) Has the construction of rights regarding information related to education in a Covid-19 atmosphere changed? (2) What is the role of related parties in the atmosphere of Covid-19 in fulfilling the right to information related to education?

This research uses normative juridical methods. Research techniques and procedures begin by identifying the provisions of national and international laws related to human rights in general, the right to education and the right to information and national education. The legal provisions referred to are, the 1945 Constitution of the Republic of Indonesia / UUDN RI 1945, Law Number 39 of 1999 concerning Human Rights, Law Number 20 of 2003 concerning the National Education System of the National Education System and provisions of international law, namely the Universal Declaration of Human Rights. 1948 and the International Covenant 
on Economic, Social and Cultural Rights / the Covenant on Economic, Social and Cultural Rights.

Existing legal provisions are subject to legal review and study related to the formulation of regulations and regulatory substances which are closely related to the scope of the regulation. The results of the study and study of the concept of the right to education and the right to information are compared with how they are fulfilled in both the normal situation and the atmosphere of the Covid-19 Pandemic. The results of studies and studies regarding the importance of the right to information related to education in the atmosphere of the Covid-19 Pandemic are used as a reference for fulfilling the right to information and involving all related parties.

\section{Results and Discussion}

\section{Construction of Rights on Education in the Covid-19 Pandemic Atmosphere}

The right about education and the right about information are both human rights protected by the 1945 Indonesian Constitution. Both human rights are closely related when the right about information is also seen as a right regarding of education. On the other hand, the right about education is also closely related to the right about information. This is understandable considering that these two human rights are part of human rights for self-development. A person has human rights to develop himself through education and information received. Although both are closely related to the right to self-development, the two human rights have differences. It will be further explained the nature of the right about information and the right about education and the importance of the right about information related about education during the Covid-19 Pandemic.

The right about education as a human right was regulated in Article $28 \mathrm{C}$ of the Indonesian Constitution. That affirmed the right about education in 2 (two) main parts.

First, the right about education is the right to develop oneself as the fulfilment of basic needs, to get education and to benefit from science and technology, arts and culture. In other words, the fulfilment of the right about education is closely related to fulfilling basic needs, getting education and obtaining benefits from science and technology, arts and culture. The important point emphasized by Article 28C of the 1945 Indonesian Constitution lies in education as a basic need as well as a need for self-development. When associated with urgent needs in humans, education is an essential need as well as a necessity for existence. Through mastery of education, a person not only gets recognition but also gets fulfilment of his basic needs for life. Therefore, the right about education is closely related to the fulfilment of basic human needs for life, especially from an economic and social perspective.

Second, the importance of this right about education is emphasized "for the sake of improving the quality of life and for the welfare of mankind." This second main point further emphasizes that the right about education is not merely about the measurable acquisition of knowledge from the acquisition of a degree. The right about education is so broad because it involves efforts to improve the quality of life and human welfare. This means that the right about education is multi-aspect related to one another, economic aspects, social aspects, cultural aspects, and even other aspects.

Furthermore, this right about education will be linked to Article 26 Paragraph (1) of the DUHAM has a different understanding. Article 26 Paragraph (1) DUHAM regulates the right about education as the "right about education". In an effort to ensure the fulfilment of the right 
about education, it is necessary to provide free education, especially at low school levels and basic education. The DUHAM emphasizes the right about education more on the important things that must be in place to ensure its fulfilment. The interesting thing about Article 26 Paragraph (1) of the UDHR, is that the right about education is based on 4 (four) main principles, first is the principle of equality of opportunity, second is the principle of respect for human rights and basic freedoms, the third is the principle of tolerance for peace and the four principles the main rights of parents regarding the choice of education for children.

The first principle provides guarantees about equal opportunities to obtain education in a fair way (Article 26 Paragraph (1) UDHR). Explicitly, this first principle emphasizes the importance of a reasonable way for all people to enter education without differentiating one's social, economic and background status. The second principle emphasizes the essence of the right about education as a concrete form of human appreciation for human rights (Article 26 Paragraph (2) DUHAM). The third principle is not much different from the second principle, it's just that the emphasis is on educational content / material that must teach tolerance for mutual peace.

The fourth principle emphasizes something different from the previous three principles. If the orientation of the previous three principles emphasizes the guarantee and protection of the right about education, the fourth principle seems to give that right to parents. Basically, this understanding is incorrect considering Article 26 of the DUHAM emphasizes the right about education. That is, guarantees about the right about education remain with each person, only when he is still at the age of a child the parents have the main right (Article 26 Paragraph (3) DUHAM). The choice of education is certainly not as desired by the parents but the best education for children.

Table 1. Material of Articles 13,14 and 15 of the Covenant on ECOSOB Rights

\begin{tabular}{|l|l|}
\hline \multicolumn{1}{|c|}{$\begin{array}{c}\text { Pasal 13 the Covenant } \\
\text { on ECOSOB Rights }\end{array}$} & \multicolumn{1}{c|}{ The regulated Material } \\
\hline Number 1 & $\begin{array}{l}\text { 1. Recognition of the right on education; } \\
\text { The direction of education for the development of the whole human } \\
\text { personality and self-awareness as part of human rights and basic } \\
\text { freedoms; }\end{array}$ \\
$\begin{array}{l}\text { 3. Effectively freely participation; } \\
\text { 4. Mutual understanding, tolerance and friendship without } \\
\text { discrimination leads to peace }\end{array}$ \\
\hline Number 2 & $\begin{array}{l}\text { Strive to the fullest: } \\
\text { 1. Free and compulsory basic education; } \\
\text { 2. Available and open of secondary education to anyone in an } \\
\text { appropriate manner; }\end{array}$ \\
$\begin{array}{l}\text { 3. Equally Higher education available according to ability with all } \\
\text { appropriate means; }\end{array}$ \\
$\begin{array}{l}\text { 4. Encouraging the fulfillment of basic education for people who have } \\
\text { not; }\end{array}$ \\
$\begin{array}{l}\text { 5. Development of the education system with continuous improvement } \\
\text { of teachers. }\end{array}$ \\
$\begin{array}{l}\text { Respect the freedom of parents to choose schools for children according } \\
\text { to the minimum standard of state education and guarantee religion and } \\
\text { morals according to their beliefs. }\end{array}$ \\
\hline Number 3
\end{tabular}




\begin{tabular}{|l|l|}
\hline Number 4 & $\begin{array}{l}\text { Freedom to establish educational institutions for the sake of } \\
\text { implementing numbers 1 to 3 }\end{array}$ \\
\hline Pasal 14 Covenant on ECOSOB Rights \\
\hline \multicolumn{1}{|c|}{ Pasal 14 Kovenan } & $\begin{array}{l}\text { Countries that have not been able to implement compulsory basic } \\
\text { education must carry out an action plan }\end{array}$ \\
\hline Pasal 15 Covenant on ECOSOB Rights \\
\hline Number 1 & $\begin{array}{l}\text { 1. The right to take part in cultural life; } \\
\text { 2. The right to get the benefits of scientific progress and its application; } \\
\text { 3. The right to get benefit from the protection of moral and material } \\
\text { interests from the created scientific, literary or artistic work }\end{array}$ \\
\hline Number 2 & $\begin{array}{l}\text { The obligation of the state to determine the preservation, development } \\
\text { and dissemination of science and culture. }\end{array}$ \\
\hline Number 3 & $\begin{array}{l}\text { The obligation of the state to respect absolute freedom for scientific } \\
\text { research and creative activity }\end{array}$ \\
\hline Number 4 & $\begin{array}{l}\text { The obligation to recognize the benefits of the promotion and } \\
\text { development of international relations and cooperation in the field } \\
\text { science and culture. }\end{array}$ \\
\hline
\end{tabular}

Based on these three legal provisions, the EKOSOB Rights Covenant emphasizes 4 (four) important things, first the recognition of the right Higher about education and its benefits, secondly participation in education, the three directions and substance of education and the four obligations of parties related about education. The first thing has a difference with the right about education Article 26 DUHAM. The broader provisions of the ECOSOC Rights Covenant focus not only on the right about education but on the right about education. This is understandable considering the importance of the right about education as the key to the fulfilment of a person's economic, social and political rights in society.7 Similar but not the same, the ECOSOB Rights Covenant emphasizes that the right about education is not merely the right to access education but also the right to benefit and contribute from science and technology (Article 15 Number 1 of the Covenant on ECOSOB Rights).

The second issue regarding educational participation also emphasizes new things besides the effective participation of all parties (Article 13 Number 4 of the EKOSOB Rights Covenant) and freely emphasizes the freedom to establish educational institutions and guarantees of basic education by the State (Article 14 of the Covenant on ECOSOB Rights). The direction and substance of education also have the same emphasis as Article 26 of the UDHR. The fourth thing is something new regarding the obligations of parties related about education, the state, education providers, educators, and parents.

This international legal instrument has been ratified by Indonesia through Law Number 11 of 2005 concerning Ratification of the International Covenant on Economic, Social and Cultural Rights (International Covenant on Economic, Social and Cultural Rights). The Covenant on Economic, Social and Cultural Rights has also become a reference in understanding rights in the field of economic, social, and cultural rights. Although this international legal instrument was only ratified in 2005, the 1945 Indonesian Constitution has affirmed the right about education long beforehand in Article 28C. It appears that the regulation of the right about education in Indonesia is in conformity with Article 13-Article 15 of the Covenant on ECOSOB Rights. The matters stipulated in Article 28C of the 1945 Indonesian Constitution are more summarized in two main discussion points, the first is the right about education, which is the right to develop oneself as a fulfilment of basic needs, to get education and to benefit from 
science and technology, arts and culture and second, the importance of rights. This education also emphasized "for the sake of improving the quality of life and for the welfare of mankind". This means that the four important things in Article 13 - Article 15 of the Covenant on Economic and Social Rights of the Republic of Indonesia have been contained in Article 28C of the 1945 Indonesian Constitution (Table 2).

Table 2. Comparison of the substance of the EKOSOB Rights Covenant and the 1945 Indonesian Constitution on the Right about education

\begin{tabular}{|c|c|}
\hline $\begin{array}{c}\text { Substansi } \\
\text { Pasal 28C UUDNRI } 1945\end{array}$ & $\begin{array}{c}\text { Substansi } \\
\text { Pasal 13-15 Kovenan Hak EKOSOB }\end{array}$ \\
\hline $\begin{array}{l}\text { Self-development rights as fulfillment of basic needs } \\
\text { and benefits }\end{array}$ & $\begin{array}{l}\text { Rights regarding education and its } \\
\text { benefits }\end{array}$ \\
\hline $\begin{array}{l}\text { Self-development rights as fulfillment of basic needs } \\
\text { and benefits }\end{array}$ & Participation in education \\
\hline $\begin{array}{l}\text { The right to improve the quality of life and mutual } \\
\text { welfare }\end{array}$ & $\begin{array}{l}\text { Direction and substance of } \\
\text { education }\end{array}$ \\
\hline $\begin{array}{l}\text { The right to improve the quality of life and mutual } \\
\text { welfare }\end{array}$ & $\begin{array}{l}\text { Obligations of parties related } \\
\text { about education }\end{array}$ \\
\hline
\end{tabular}

Sumber: UUDN RI 1945, Kovenan Hak EKOSOB

Based on Table 2, Indonesia is normatively juridically committed to fulfilling the right about education both from the nature of education, direction and substance, participation or opportunity and related parties in education. Indonesia's readiness in defining the right about education is further stipulated in Law 20 of 2003 concerning the National Education System.

Susani Triwahyuningsih (2018: 113-120) the step to include the right about education in law is a strategic step for the protection of human rights. The interesting thing is that in the Advisory Section of the National Education System Law, it is understood that the fulfilment of the right about education has a solid foundation as an effort to realize the goals of the state, the constitutional mandate to increase faith and noble morals in order to educate the nation's life and the arrangement of the previous national education system which is not in accordance with the amendments to the 1945 Indonesian Constitution. Philosophically, the fulfilment of the right about education is an effort to create intelligent humans and participate in world order. Therefore the right about education is so important.

Since enacted on July 8, 2003, the National Education System Law has not changed. The Legal Analysis and Evaluation Report on the National Education System, BPHN recommends changes to the applicable national education system considering that it is no longer suitable with the development of society and information technology (Eko Suparmiyati, 2018). However, the National Education System Law is still a reference until a new law is issued. The National Education System Law emphasizes a basic understanding of "education" as "a conscious and planned effort to create an atmosphere of learning and the learning process so that students actively develop their potential to have religious spiritual strength, self-control, personality, intelligence, noble character, and the necessary skills. himself, society, nation and state "(Article 1 Part 1 of the National Education System Law)

Based on this definition, education includes aspects of planning, learning processes and objectives. The planning aspect of learning is seen in the word "conscious and planned effort", meaning that education is not carried out without mental awareness. Education as a conscious and planned effort means that education must be carried out with a sense of responsibility and 
make plans, methods, and evaluations to achieve predetermined learning objectives. In this regard, the National Education System Law introduces the term 'curriculum'.

Likewise, with the learning process, the education carried out does not only focus on students, but involves educational staff to support the learning process. Regarding the learning process, learning materials and material delivery models, information technology can be used. The third aspect which is also important in understanding education is closely related to learning objectives so that students actively develop their full potential, which means that it is directed at developing religious spiritual strength, self-control, personality, intelligence, noble morals and skills needed by themselves and their communities (Article 1 point 1 of the National Education System Law). Therefore, in the thought of the National Education System Law, education is not just providing learning material without a clear learning design and learning objectives.

As an effort to realize a good national education system, the National Education System Law introduces 3 (three) educational channels, formal education as a structured and tiered education pathway starting from primary education, secondary education and higher education, non-formal education as a path of education outside formal education and informal education. as a channel for family and environmental education (Article 1 Figures 11, 12 and 13 of the National Education System Law). Each of these educational paths is different from one another. This can be seen in the following table 3:

Table 3. Pathways of education, formal education, non-formal education, and informal

\begin{tabular}{|l|l|l|l|}
\hline \multicolumn{1}{|c|}{ Subject } & \multicolumn{1}{|c|}{ Formal education } & nonformal education & \multicolumn{1}{c|}{$\begin{array}{l}\text { informal } \\
\text { education }\end{array}$} \\
\hline Purpose & Academic mastery & $\begin{array}{l}\text { Substitute, supplementary and / or } \\
\text { complementary services for formal } \\
\text { education }\end{array}$ & Nothing \\
\hline Function & $\begin{array}{l}\text { Knowledge and } \\
\text { technology provision }\end{array}$ & $\begin{array}{l}\text { Developing potential and long-life } \\
\text { education }\end{array}$ & $\begin{array}{l}\text { Independent } \\
\text { study activities }\end{array}$ \\
\hline Level & $\begin{array}{l}\text { Primary education, } \\
\text { secondary education } \\
\text { and higher education }\end{array}$ & Can be tiered & Nothing \\
\hline Executor & $\begin{array}{l}\text { Government, Local } \\
\text { Government and / or } \\
\text { society }\end{array}$ & $\begin{array}{l}\text { Course institutes, training institutes, } \\
\text { study groups, learning activity } \\
\text { centers, etc. }\end{array}$ & $\begin{array}{l}\text { Family and } \\
\text { environment }\end{array}$ \\
\hline $\begin{array}{l}\text { implementati } \\
\text { on }\end{array}$ & $\begin{array}{l}\text { Face to face and / or } \\
\text { remotely }\end{array}$ & Face to face and / or remotely & $\begin{array}{l}\text { Face to face and } \\
\text { / or remotely }\end{array}$ \\
\hline
\end{tabular}

Sumber: UU Sisdiknas, 2003

Although the three educational pathways have differences, they must complement and enrich each other (Article 13 of the National Education System Law). And what is more interesting from table 3 is that the implementation of education is related to the Covid-19 Pandemic.Education in the Covid-19 Pandemic atmosphere provides challenges to the learning design, the learning process but not the learning objectives. As emphasized in the PSBB policy which emphasizes social restrictions, including the implementation of education at home. Educational efforts from the learning design and learning process need to be studied, especially 
by using information technology. The use of information technology in the education process has basically been introduced in Article 1 point 15 of the National Education System Law as a distinctive form of education. Distinctive characteristics of distance education appear in the condition that educators and students are separated, and learning uses various sources through communication technology, information technology and other media. Emphasis of the form of distance education is not only on distance or conditions without face to face but the use of technological media, including information technology. Regulating the form of Distance Education in Article 31 of the National Education System Law can be implemented in all channels, all levels and types of education in a condition where people cannot attend face-toface or regular education. Based on this, distance education is an educational program that has been considered by the Government.

The following discussion relates to the correlation between long distance education and online learning. The use of the two terms often interchangeably seems to have the same meaning, but they are not. Distance education as described in Article 1 point 15 of the National Education System Law is an educational program with special conditions, namely the separation of educators and students from the use of information technology. It should be remembered that the scope of long-distance education is so broad and even flexible because it relies on the use of communication media and information technology, not only the internet. Paulina Pannen, explained that: online learning is a learning process characterized by the use of various communication media in conditions that educators and students may be geographically separated which can be done in combination with face-to-face learning.

That is, online learning on the one hand has the same characteristics as distance education in terms of learning methods using information technology (internet) media, but on the other hand it also has differences. Online learning is basically a less flexible and less open learning method whereas distance education is more flexible and open with greater student autonomy. Therefore, online learning in the conditions of using information technology is not necessarily said to be distance education as referred to in Article 1 number 15 of the National Education System Law. Online learning can be part of a method of learning in long distance education when it has been systematically designed or planned by the education provider institution. Thus, the use of information technology in formal, non-formal or informal education cannot necessarily be referred to as distance education.

Long distance education has specifically regulated the requirements in the National Education System Law, Article 31 Paragraph (3) of the National Education System Law emphasizes the administration of "Distance education is held in various forms, modes and coverage supported by learning facilities and services as well as an assessment system that guarantees the quality of graduates accordingly. with national education standards. "

Based on these regulations, distance education is an educational program. Laong dstance education includes education based on subjects / subjects based on fields of study (Elucidation of Article 31 Paragraph (3) of the National Education System Law). Long distance education does not necessarily guarantee that learning materials are delivered according to the quality and national education standards. The main message of Article 31 of the National Education System Law, long distance education must still involve learning preparation in the form, mode, and scope of planned learning from the beginning, through the process to the evaluation of learning. Exactly as emphasized by the Regulation of the Minister of Education and Culture of the Republic of Indonesia Number 3 of 2020 (Permendikbud RI No.3 of 2020) which regulates detailed National Education Standards.

Article 4 Permendikbud RI No. 3 of 2020 states that there are at least 8 (eight) National Education Standards that must be met (a) competency standards of graduates, (b) learning 
content standards, (c) learning process standards, (d) learning education assessment standards, (e) Lecturer standards and Education Personnel, (f) standard of learning facilities and infrastructure, (g) standard of management and (h) standard of learning financing. In line with these educational standards the learning process, the use of information technology must also be supported by learning facilities and services. In this section, distance education also requires equal opportunities for both educators and students regarding learning facilities and services.

The absence of learning facilities and services in distance education for the sake of implementing formal education is not possible. In line with the importance of the availability of learning facilities and services, understanding the right about information becomes increasingly important. Article 28F of the 1945 Indonesian Constitution states that "Everyone has the right to communicate and obtain information to develop their personal and social environment, as well as the right to seek, obtain, possess, store, process, and convey information using all available channels." Once again, the emphasis of Article 28F of the 1945 Republic of Indonesia UUDN affirms that the right about information functions as a self-development and social environment. The right about information in the formulation of Article 28F of the 1945 Indonesian Constitution is more oriented to the right to obtain information.

It means that the acquisition of information is the main emphasis in an effort to make it easier for information to be obtained. This is closely related to the right about education during the Covid-19 Pandemic. The right about education is closely related to the right about information. Education during a pandemic is challenged by the problem of distance that separates educators and students. The use of internet media has become a mainstay in bridging the needs of "classrooms" in the internet world. This means that this pandemic period has emphasized the close relationship between the right about education and the right about information. This idea is in accordance with Articles 13-15 of the Covenant on Economic and Social Rights and Article 28C of the 1945 Constitution of the Republic of Indonesia. That human rights are related among one another and even affirm the importance of human rights in their fulfilment.

The National Education System Law has introduced Distance Education using information technology as a rational effort to fulfil the right about education during a pandemic and does not simply one to be acted. The use of internet media for educational purposes cannot be separated from guaranteeing the fulfilment of the right about information. The ability to access the internet is a need that needs to be considered when internet media-based distance education is to be carried out. In normative juridical terms, the Human Rights Law affirms the right about information as part of the right to benefit from science and technology (Article 13) including the right to use all available facilities, including information technology (pasal 14 Paragraph (2)

\section{Efforts to Fulfill the Right about information related to education during the Covid-19 Pandemic}

The fulfilment of the right about information related about education must once again pay attention to the 2 human rights contained therein, the right about education and the right about information. Like two sides of a coin, the two rights are intertwined in fulfilling them. The fulfilment of the right about education is very dependent on the right about information, and vice versa. The fulfilment of the right about education has basically been emphasized as the main right that must be considered during the Covid-19 Pandemic. Social distancing should not be interpreted as reducing the right about education. The PSBB strategy as described in the Health Quarantine Law does not exclude the right about education at all. In fact, during the PSBB era, the right about education must be fulfilled as much as possible. 
The challenges faced during the Covid-19 Pandemic are in terms of learning methods and supporting learning facilities. This is closely related to the readiness of online learning methods or distance education, on the one hand, supported by adequate information technology facilities. Fulfilling the right about education during the Covid-19 Pandemic cannot be separated from the use of internet media. The learning method must also change in terms of the way of delivery and the interaction model used. If previously all educational pathways used face-to-face methods, this time the meeting was held online. The material presentation must also be packaged more densely, more attractive and more persuasively. Even though you cannot meet physically or face-to-face, one characteristic of the learning process that remains is interaction. The use of the internet in various media platforms, from Zoom, Google Meet, Cisco Webex, and other media provides various facilities that make it easier for both educators and students. The problem actually arises in terms of the adaptability of the education staff and students about the media used.

The fulfilment of this right about education is the responsibility of the government based on Article 8 of the Human Rights Law. Hernadi Affandi,(2017) revealed that the fulfilment of the right about education can be successful when emphasizing the protection, promotion, enforcement and fulfilment of the rights about education itself. Contextually, the fulfilment of the right about information related to education in the pandemic atmosphere is also related to the availability of supporting information technology facilities.

Dina Indriyani (2018: 1-12) emphasizes that this aims to ensure equitable distribution of education so that it is affordable to the community. The view of equal distribution of education during the pandemic also needs to refer to Tomasevski's (2001) view regarding 4 (four) indicators of fulfilling the right to education, namely: available, accessible, acceptable and adaptable. Based on these four principles, the government through the Ministry of Communication and Information Technology of the Republic of Indonesia provides services through several developments in telecommunications and internet infrastructure. Komkominfo RI stated that there are at least 2 (two) programs related to telecommunication infrastructure and the provision of internet access as the government's commitment to equal rights regarding information.

First, information and communication technology infrastructure in the progress of Palapa Ring development for the development of a national fiber optic broadband backbone network. Palapa Ring is a telecommunications infrastructure program that will guarantee broadband services from 514 districts / cities in Indonesia as a target for 2019, which is a new indicator of the fulfilment of the right to information. Second, Provision of Base Transceiver Station (BTS) infrastructure in the form of cellular network towers in non-commercial areas / blank spot areas, especially in border and hinterland areas (3T, underdeveloped, outermost and frontier areas) that have not been reached by private telecommunications operators. The results are in accordance with Presidential Decree Number 131 of 2015 and Perka BNPP Number 1 of 2015, at the end of December 2018 there were 427 BTS out of the target of 575 locations in 2019. Efforts to provide internet access, the Ministry of Communication and Information of the Republic of Indonesia stated that there were 4,111 internet access points spread across 34 provinces through Vsat device with access speed of $2 \mathrm{Mbps}$, Fiber Optic or RadioLink.

This data shows that the Ministry of Communication and Information of the Republic of Indonesia has prioritized the right to education through fulfilling the right to information by building telecommunications infrastructure and internet access. Emmanuel Sujatmoko (2010) revealed that the location where the construction was carried out was more focused on the location of the school, which shows the government's commitment to education. This is very important considering that the fulfilment of the right to education does not only depend on legal 
arrangements but on the commitment of education funding by the government. Telecommunication infrastructure and internet access although not yet maximally fulfilled, at least in the process of fulfillment for the community.

A further challenge is related to the readiness of learning methods and online-based learning tools. Online learning methods are different from face-to-face learning. Education personnel need to learn about the facilities and how to use this online media. Distance constraints are basically not a problem in online learning. Education personnel need to prepare materials, learning facilities, and media to be used as well as internet access. The learning facilities meant are the availability of computers, laptops and other electronic devices that have internet access. Electronic devices that do not have internet access are a separate obstacle, not to mention the accessibility of these devices to learning media. Internet access is also important to ensure that internet connectivity basically brings together educators and students.

Fulfilling internet access has two aspects, the level of electronic device technology and internet quota. Regarding the level of technology, it basically includes electronic devices that can be used whether they are connected to the internet or not. The important thing is the internet quota which is directly related to financing. Fulfilling internet quota is basically not a problem if you are connected to the school or campus internet network internally. This condition is not possible considering the Covid-19 Pandemic and PSBB which implemented work from home. Internet quota is also an obstacle in fulfilling the right to education related to the right to information.

The conditions are not much different from those faced by students in online learning. As subjects in the learning process, students also adapt to changes in learning designs related to learning methods and educational facilities. Although this generation is a millennial generation that is adaptive to information technology, especially the internet. This does not mean that the mastery of information technology (digital literacy) is automatically mastered. Students need to get basic supplies in finding, selecting, sorting, processing and using the information available appropriately. The choice of online learning methods using media such as zoom, Cloud-X, and other media also provides its own challenges for students to adapt.

Not to mention the readiness of facilities and internet access, not all students have the same abilities and opportunities. The right to information related to education is an urgent matter for students to think about by related parties in its fulfilment. In this regard, the fulfilment of education involves at least 5 (five) parties, the government, education providers, educators, parents / community and students. The duties and obligations of the parties in fulfilling the right to information related to education can be described in Table 4.

Table 4. Duties and Obligations of the Parties regarding Distance Education

\begin{tabular}{|l|l|l|l|}
\hline & \multicolumn{1}{|c|}{ Learning Preparation } & Learning process & \multicolumn{1}{|c|}{ facilities } \\
\hline Government & $\begin{array}{l}\text { Direction of national } \\
\text { education policy }\end{array}$ & $\begin{array}{l}\text { Forms of Distance } \\
\text { Education }\end{array}$ & $\begin{array}{l}\text { Availability of } \\
\text { telecommunication } \\
\text { infrastructure and } \\
\text { tours } \\
\text { Internet access }\end{array}$ \\
\hline $\begin{array}{l}\text { Education } \\
\text { provider }\end{array}$ & $\begin{array}{l}\text { Curriculum according } \\
\text { to national standards } \\
\text { Education }\end{array}$ & $\begin{array}{l}\text { Facilities and online } \\
\text { learning media }\end{array}$ & $\begin{array}{l}\text { Support for internet } \\
\text { access facilities and } \\
\text { funds }\end{array}$ \\
\hline
\end{tabular}




\begin{tabular}{|l|l|l|l|}
\hline Teacher & Lesson plan & $\begin{array}{l}\text { Online learning methods } \\
\text { are interactive and } \\
\text { persuasive }\end{array}$ & $\begin{array}{l}\text { The readiness of } \\
\text { facilities and internet } \\
\text { access is prime }\end{array}$ \\
\hline $\begin{array}{l}\text { Parents / } \\
\text { community }\end{array}$ & Optimal support & Optimal support & $\begin{array}{l}\text { The readiness of facilities } \\
\text { and internet access }\end{array}$ \\
\hline student & $\begin{array}{l}\text { Understanding Lesson } \\
\text { Plans }\end{array}$ & $\begin{array}{l}\text { Mastery of the learning } \\
\text { fesponsive and actively } \\
\text { facilities and media used. }\end{array}$ \\
\hline
\end{tabular}

The five parties basically have their respective parts in fulfilling the right about information related about education. The government cannot fulfil the right about information related about education independently. The synergy of the five parties is the key to the success of fulfilling the right about information related about education. The fulfilment of the right about education does not only lie in the implementation of education but involves all parties to fulfill each other's share.

\section{Conclusion}

The implementation of education is a right regarding education which is protected by the 1945 Indonesian Constitution and confirmed in the Human Rights Law. The construction of rights regarding education has changed in the atmosphere of the Covid-19 Pandemic. Initially, the right about education was only understood as the right to obtain education in face-to-face education programs. Broader understanding of the right about education as the right to obtain educational services in various forms / methods of learning online. Learning using the internet media, provides confirmation of the fulfilment of the right about education is closely related to fulfilling the right about information. The fulfilment of the right about education through the internet can be fulfilled if the right about information is fulfilled. The fulfilment of the right about education related to the use of internet media has been regulated in the National Education System Law as distance education.

The use of internet media during the Covid-19 Pandemic does not mean the same as distance education. Distance education is an educational program that is systematically organized and planned from the start by emphasizing the autonomy of students. Unlike the case with online learning through the use of internet media which is less flexible and becomes an alternative learning method.

The fulfillment of the right about education in relation to the right about information depends on the parties such as: the government regarding education and learning policies that are still not well organized during the Covid-19 Pandemic, Education Providers related to online learning systems and methods to be designed and used, Participants Educate in terms of willingness to learn even through online and parents / communities who are still constrained in various social and economic situations.

\section{References}

[1] Affandi, Hernadi. "Tanggung Jawab Negara Dalam Pemenuhan Hak Tentang Pendidikan Menurut Undang-Undang Dasar Tahun1945.” Jurnal Hukum Positum 1, no. 2 218-243. (2017)

[2] Ali, S. K. Jahangir. "Cultural and Educational Rights of Minorities: A Human Right and Constitutional Law Perspective.” Indian Journal for Social Studies and Humanities 1, no. 2: 1-14. (2013) 
[3] APJII. Penetrasi \& Profil Perilaku Pengguna Internet Indonesia Tahun 2018. Apjii, 2019. www.apjii.or.id.

[4] Indriyani, Dina. "Hak Asasi Manusia Dalam Memperoleh Pendidikan.” Jurnal Pendidikan Hukum, Politik dan Kewarganegaraan 7, no. 8:1-12. (2018)

[5] https://jurnal.unsur.ac.id/jpphk/article/view/3 92.

[6] Kementerian Komunikasi dan Informatika. Laporan Tahunan Kementerian Komunikasi Dan Informatika Tahun 2018. Jakarta, 2018. https://web.kominfo.go.id/sites/default/files/L APORAN TAHUNAN KOMINFO 2019 LOW \%287\%29.pdf.

[7] https://www.kompas.com/tren/read/2020/03/ 16/195035165/jokowi-instruksikan-bekerja-dariumah-ini-arti-work-from-home.

[8] Pannen, Paulina. "Moda Pembelajaran Daring/Pendidikan Jarak Jauh Yang Berkualitas", Online Seminar Asosiasi Badan Penyelenggara Perguruan Tinggi Swasta Indonesia (ABPPTSI), 25 Juli 2020

[9] Sujatmoko, Emmanuel. "Hak Warga Negara Dalam Memperoleh Pendidikan.” Jurnal Konstitusi 7, no. 1: 181-212. (2010)

[10] Suparmiyati, Eko, and dkk. Laporan Akhir Kelompok Kerja Analisis Dan Evaluasi Hukum Mengenai Sistem Pendidikan Nasional,2017.

[11] https://www.bphn.go.id/data/documents/ae_si sdiknas.pdf.

[12] Susilo, Ignatius Bagus, and et.al. Kompilasi Instrumen Internasional Hak Asasi Manusia. Surabaya: Pusat Studi Hak Asasi Manusia Universitas Surabaya, 2003.

[13] Tomasevski, K. Right about education Primers No.3: Human Rights Oblications: Making Education Available, Accessible, Acceptable and Adaptable. Swedish International Development Cooperation Agency, 2001.

[14] Triwahyuningsih, Susani. "Perlindungan Dan Penegakan Hak Asasi Manusia (HAM) Di Indonesia." Legal Standing: Jurnal Ilmu Hukum 2, no. 2: 113-120. (2018)

[15] Viviansari, Disca Betty; Prameswari, Zendy Wulan Ayu widhi. "Tanggung Jawab Negara Terhadap Hak Tentang Pendidikan Anak Buruh Migran Indonesia Di Malaysia.” Jurnal HAM 10, no. 3: 